\title{
Ewolucja rozwiązań prawych w sferze podatku przemysłowego jako element polityki podatkowej państwa polskiego w okresie międzywojennym
}

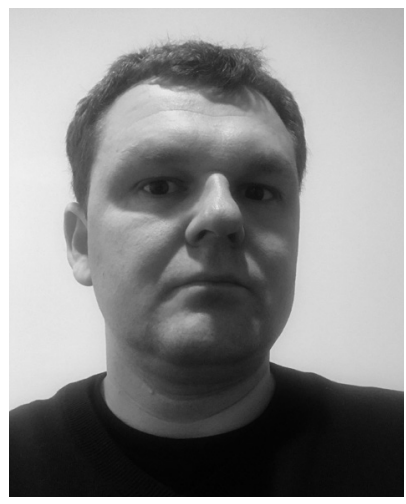

\section{Sebastian Kwiecień}

Doktor habilitowany nauk prawnych, adiunkt na Prawa Pracy i Ubezpieczeń Społecznych, Wydziału Prawa, Prawa Kanonicznego i Administracji Katolickiego Uniwersytetu Lubelskiego Jana Pawła II, radca prawny. Swoje zainteresowania naukowe kieruje w stronę praktycznych zagadnień zwiąanych z podejmowaniem i wykonywaniem działalności gospodarczej $w$ Polsce okresu międzywojennego, również w kontekście regulacji z zakresu prawa pracy.

$\triangle$ seba@kul.pl

https://orcid.org/0ooo-0003-4858-794X

\section{The Evolution of Legal Solutions in the Field of Industrial Tax as Element of Tax Policy of the Polish State During Interwar Period}

\begin{abstract}
Industrial tax, based on archaic solutions, has aroused opposition since the beginning of its operating, especially in the context of the introduction of turnover tax which was given the features of consumption tax, and the maintained industrial certificates were given the features of revenue tax. It should also be remembered that the industrial tax acts were extremely complicated in their content, the legislator in one act tried to regulate as many economic issues as it was possible. Adopted solutions concerning industrial tax allowed the legislator to obtain permanent incomings to the state budget, the size of which, however, varied depending on the period and the social and economic situation, on average constituted $10 \%$ of the total revenues of the state budget. Attempts to rationalize the system of collecting industrial tax and breaking with the principle of unevenness of this tax, therein a mechanical combination of income tax and turnover tax, were made by the Act of 25 April 1938 on turnover tax. The tax reform was the result of changes in the tax system long awaited by entrepreneurs, mainly in the area of industrial tax. Unfortunately, due to the start of the war, the regulations did not enter into force.
\end{abstract}

Słowa kluczowe: polityka podatkowa, podatek przemysłowy, świadectwo przemystowe, podatek obrotowy, przedsiębiorstwo Key words: tax policy, industrial tax, industrial certificate sales tax, enterprise

https://doi.org/10.32082/fp.v0i3(59).259 


\section{Wprowadzenie}

Na pojęcie polityki podatkowej, będącej elementem szerszej polityki budżetowej, składa się całokształt systemu i metod podatkowych, które zapewniają państwu wpływy budżetowe gwarantujące realizację jego podstawowych zadań. Nieodłącznie wiąże się ona z ogółem decyzji czy rozwiązań prawnych w zakresie opodatkowania tak podmiotów, jak i zdarzeń prawnych adekwatnych do możliwości gospodarczych podmiotów opodatkowanych. Mówiąc o polityce podatkowej, odnosimy się zarówno do kształtu systemu podatkowego, jak i do metod podatkowych przyjętych przez państwo.

Dla należytego funkcjonowania systemu podatkowego niezbędne są dwa elementy: dobre ustawy podatkowe oraz sprawny aparat skarbowy ${ }^{1}$, które pozwolą zrealizować trzy podstawowe funkcje systemu podatkowego: fiskalną, regulującą i stymulującą. Podstawowe na kierunki oraz tempo ich rozwoju ekonomicznego i pozaekonomicznego ${ }^{3}$. Przejawem tej funkcji są niewątpliwie wszelkiego rodzaju ulgi podatkowe oraz inwestycyjne, które wpływają korzystnie na sferę prowadzonej działalności gospodarczej. Ustawodawca w omawianym okresie zdecydował się na umniejszenie swoich wpływów podatkowych, mając nadzieję, że stanie się to elementem stymulującym nie tylko dla wzrostu wartości ekonomicznej samego przedsiębiorstwa, ale również pozytywnie wpłynie np. na rynek pracy na danym terenie kraju słabiej rozwiniętego gospodarczo. Jak wskazano powyżej, gwarantem skutecznego realizowania zadań postawionych przed systemem podatkowym jest aparat skarbowy, którego odbudowę rozpoczęto na terenach byłego Królestwa Polskiego jeszcze w okresie trwania I wojny światowej. Rada Regencyjna powołała do życia Ministerstwo Skarbu,

\title{
Dla należytego funkcjonowania systemu podatkowego niezbędne są dwa elementy: dobre ustawy podatkowe
}

\author{
oraz sprawny aparat skarbowy, co pozwala \\ zrealizować trzy podstawowe funkcje systemu \\ podatkowego: fiskalną, regulującą i stymulującą.
}

znaczenie z punktu widzenia polityki podatkowej odradzającego się państwa miała przede wszystkim funkcja fiskalna, wyrażająca się w dostarczaniu dochodów do budżetu państwa ${ }^{2}$. Druga funkcja polega natomiast na kształtowaniu wielkości dochodów i majątku, będących w dyspozycji podatników; powoduje także ruch pomiędzy podmiotami gospodarczymi a budżetem. Funkcja stymulacyjna polega na wykorzystywaniu instrumentów podatkowych do pobudzania wzrostu gospodarczego, wywierania wpływu na warunki działania jednostek prywatnych i państwowych oraz

1 J. Podczaski, Linje rozwoju administracji skarbowej w Polsce, „Sprawy Skarbowe” 1926, z. 11, s. 482.

2 A. Fajferek (red.), Polityka ekonomiczna, Kraków 1999, s. 122. którego głównym zadaniem miało być przejmowanie okupacyjnych instytucji administracji skarbowej i dokonywanie w ich strukturach zmian instytucjonalnych i organizacyjnych, tak aby wraz z odzyskaniem niepodległości w sposób automatyczny zaczęły one służyć niepodległemu państwu. W pierwszej kolejności, 5 listopada 1918 r., pod jurysdykcję ministerstwa oddano skarbowe organy austriackie, a 11 listopada organy Królestwa Polskiego w części okupowanej przez Niemców. W 1919 r. ministerstwo objęło swoimi wpływami obszar Podlasia i Białostocczyzny, 8 kwietnia 1919 r. - zabór austriacki, 18 listopada 1920 r. - województwa wschodnie, 1 stycznia 1922 r. - były zabór

3 Tamże, s. 123-124. 
pruski, 24 marca 1922 r. - ziemię wileńską oraz Górny Śląsk, tym samym kończąc proces centralizacji władz administracji skarbowej ${ }^{4}$.

Pierwszym krokiem w zakresie ujednolicania struktury organów administracji skarbowej oraz systemu podatkowego stała się przygotowana w Ministerstwie Skarbu ustawa z 31 lipca 1919 r. o jednolitej organizacji władz i urzędów skarbowych ${ }^{5}$. Ten akt prawny był niecierpliwie oczekiwany, gdyż do czasu jego ustanowienia na terenie państwa funkcjonowało aż dziewięć systemów ustawodawstwa skarbowego. Ustawa swoimi regulacjami objęła początkowo terytoria województw centralnych, a od 1921 r. również ziemie włączone do Polski na mocy traktatu ryskiego ${ }^{6}$. W $1922 \mathrm{r}$. została także wprowadzona na terenie byłego zaboru pruskiego oraz ziemi wileńskiej ${ }^{7}$. Najdłużej proces

4 Nie sposób przejść obojętnie obok faktu, że w okresie największych problemów budżetowych i walki o równowagę budżetową, kiedy formowano jednolity aparat administracji skarbowej, przyznano swoistą autonomię skarbową ziemiom zaboru pruskiego. Działał tam specjalny Komisariat Naczelnej Rady Ludowej, a następnie Departament Skarbu podlegający Ministerstwu byłej dzielnicy pruskiej, co było odstępstwem od zasady centralizacji administracji skarbowej i przyczyniało się do zmniejszenia wpływów do centralnego budżetu. Zob. Z. Landau, J. Tomaszewski, Gospodarka Polski międzywojennej 1918-1939, t. 1: W dobie inflacji. 1918-1923, Warszawa [Książka i Wiedza] 1967, s. 251-152.

5 Dz.U. nr 65, poz. 391. Ustawa obowiązywała jednak dopiero od 1 kwietnia $1920 \mathrm{r}$.

6 Rozporządzenie Rady Ministrów z dnia 21 marca 1921 r. w przedmiocie rozciągnięcia mocy obowiązującej ustawy z dnia 31 lipca 1919 r. o tymczasowej organizacji władz i urzędów skarbowych na ziemie przyłączone do Rzeczypospolitej na podstawie umowy o preliminaryjnym pokoju i rozejmie, podpisanej w Rydze dnia 12 października 1920 r., Dz.U. nr 35, poz. 205.

7 Rozporządzenie Rady Ministrów z dnia 21 grudnia 1921 r. w sprawie przekazania Ministrowi Skarbu administracji skarbowej na obszarze b. dzielnicy pruskiej, Dz.U. nr 4, poz. 19; Rozporządzenie Ministra Skarbu w porozumieniu z Ministrem b. Dzielnicy Pruskiej z dnia 22 stycznia 1922 r. w przedmiocie objęcia przez Ministerstwo Skarbu administracji skarbowej na obszarze b. dzielnicy pruskiej, Dz.U. nr 11, poz. 101; Rozporządzenie Rady Ministrów z dnia 19 czerwca 1922 r. w przedmiocie tymczasowego ustroju władz unifikacji administracji skarbowej trwał w Galicji pomimo tego, że zaczął się jeszcze w 1921 r., to trwał aż do jesieni roku $1925^{\circ}$. Po tym okresie autonomiczne rozwiązania wprowadzono i utrzymano jedynie na terenie Górnego Śląska, co wynikało z uzyskanego przez to województwo statusu autonomicznego, także w zakresie skarbowości'.

O ile ujednolicenie organów administracji skarbowej nie było zadaniem łatwym, o tyle trudniejsza okazała się odbudowa systemu podatkowego i jego zunifikowanie - zarówno w kwestii rodzajów pobieranych danin czy stawek wymiarowych, jak i zasad ich pobierania. Proces ten napotkał niestety na opór społeczeństwa, gdyż niejednokrotnie wiązał się ze zwiększeniem obciążeń fiskalnych na danym terytorium lub dla określonych grup. Działania unifikacyjne utrudniał jeszcze jeden bardzo istotny element, mianowicie: ustawodawca musiał zmierzyć się z problemem różnic rozwojowych poszczególnych województw czy nawet ich poszczególnych obszarów. Te elementy ostatecznie przyczyniły się do spowolnienia procesu unifikacji systemu podatkowego w Polsce ${ }^{10}$.

skarbowych na Ziemi Wileńskiej i rozciągnięcia na tę ziemię niektórych ustaw i rozporządzeń, Dz.U. nr 51, poz. 458; Rozporządzenie Ministra Skarbu z dnia 11 lipca 1922 r. w przedmiocie utworzenia izby skarbowej i urzędów skarbowych na obszarze Ziemi Wileńskiej, Dz.U. nr 58, poz. 522.

8 Rozporządzenie Ministra Skarbu z dnia 27 kwietnia 1921 r. w przedmiocie utworzenia izb skarbowych na obszarze województw: Krakowskiego, Lwowskiego, Stanisławowskiego i Tarnopolskiego, Dz.U. nr 41, poz. 254; Rozporządzenie Ministra Skarbu z dnia 1 kwietnia 1925 r. w sprawie zmiany organizacji urzędów skarbowych w okręgach administracyjnych izb skarbowych w Krakowie, Lwowie, Łucku, Grudziądzu i Poznaniu, Dz.U., nr 38, poz. 263.

9 W zakresie autonomii województwa śląskiego odsyłam do: J. Ciągwa, Autonomia Śląska (1922-1939), Katowice 1988; J. Ciągwa, Śląskie spory o wykładnię wygaśnięcia i utraty mandatu poselskiego w Sejmie Śląskim (w:) S. Grodziski $\mathrm{i}$ in. (red.), Vetera novis augere. Studia i prace dedykowane Profesorowi Wactawowi Uruszczakowi, t. 1, Kraków 2010; S. Kwiecień, Ustrój województwa śląskiego w latach 1920 1939, „Imponderabilia” 2012, nr 4; K. Popiołek, Śląskie dzieje, Warszawa-Kraków 1976.

10 Na przykład w zaborze rosyjskim, gdzie funkcjonował najbardziej prymitywny system podatkowy, nie znano podatku docho- 


\section{Okres wielkiej inflacji i deficytu budzetowego}

Obowiązujący po odzyskaniu niepodległości system podatkowy był bez wątpienia oparty na podatkach przychodowych, a nie dochodowych, z czego wynikała ich uciążliwość dla osób fizycznych i przedsiębiorców. Nie był on też dostosowany do warunków ekonomicznych i politycznych, w tym możliwości płatniczych samych podatników, co było szczególnie widoczne w sferze obciążeń podatkowych przedsiębiorców. Utrzymanie różnych systemów podatkowych wiązało się z nierównym obciążeniem przedsiębiorców, co negatywnie wpływało na opłacalność produkcji zostać wprowadzony na terenie całego kraju - właśnie w oparciu o rozwiązania rosyjskie. Trzeba pamiętać, że przedsiębiorcy w okresie międzywojennym byli również zobowiązani do opłacania podatków dochodowych, majątkowych, pośrednich oraz licznych innych danin publicznych będących źródłem dochodu państwa i jednostek samorządu terytorialnego ${ }^{12}$.

Na rok 1920 przypadły pierwsze zasadnicze reformy systemu podatkowego w Polsce, $w$ tym podatku przemysłowego. Zreformowano wówczas podatek od spadków i darowizn według stawek progresywnych ${ }^{13}$. Uchwalono ustawę o podwyżce podatku gruntowego w byłym Królestwie Polskim ${ }^{14}$, ustawę o podatku od

\section{Obowiązujący po odzyskaniu niepodległości system} podatkowy był bez wątpienia oparty na podatkach przychodowych, a nie dochodowych, z czego wynikała jego uciążliwość dla osób fizycznych i przedsiębiorców.

i konkurencyjność tak samych przedsiębiorców, jak i oferowanych przez nich produktów oraz usług. Jest to o tyle istotne, że - co przedstawię w dalszej części artykułu - to przedsiębiorcy zostali obciążeni zapewnieniem dochodu, który był niezbędny do przeprowadzenia niezbędnych reform, w tym walutowej ${ }^{11}$.

Instrumentem pozyskiwania stałych dochodów budżetowych miał się stać opłacany przez przedsiębiorców przychodowy podatek przemysłowy. Co ważne, po odzyskaniu niepodległości był on znany jedynie na terenie byłego zaboru rosyjskiego, miał zaś

dowego, a pozostałe podatki przychodowe skonstruowane były w analogii do rozwiązań feudalnych, opartych na podatkach gruntowych, włościańskich i dworskich. Podatki dochodowe istniały na terenie byłych zaborów pruskiego i austriackiego, jednak w tym drugim opłacane były wyłącznie przez osoby fizyczne. Zarówno na ziemiach byłego zaboru rosyjskiego, jak i austriackiego podatki pośrednie (akcyzy, monopole skarbowe, cła) stanowiły główne źródło dochodu państwa.

11 E. Taylor, Prawo skarbowe Rzeczypospolitej Polskiej, cz. 2, Poznań 1920, s. 173. kapitałów i rent ${ }^{15}$, ustawę o podatku dochodowym i majątkowym ${ }^{16}$, a także podwyższono podatek gruntowy na obszarze byłego zaboru austriackiego ${ }^{17}$.

Uchwalono również ustawę z 6 lipca 1920 r. dotyczącą ujednostajnienia na obszarze byłego zaboru rosyjskiego ustaw i rozporządzeń o podatku prze-

12 Zob. S. Kwiecień, Polskie prawo gospodarcze okresu międzywojennego, Lublin 2016, s. 199-260.

13 Ustawa z dnia 29 maja 1920 r. w przedmiocie zmiany przepisów o opodatkowaniu spadków i darowizn, Dz.U. nr 49, poz. 299.

14 Ustawa z dnia 14 lipca 1920 r. o ujednostajnieniu i podwyższeniu podatków gruntowych i podymnego na obszarze b. Królestwa Kongresowego, Dz.U. nr 71, poz. 477.

15 Ustawa z dnia 16 lipca 1920 r. o podatku od kapitałów i rent, Dz.U. nr 76, poz. 517.

16 Ustawa z dnia 16 lipca 1920 r. o państwowym podatku dochodowym i podatku majątkowym, Dz.U. nr 82, poz. 550.

17 Ustawa z dnia 14 lipca 1920 r. o podwyższeniu podatku gruntowego na obszarze b. zaboru austrjacko-węgierskiego, Dz.U. nr 61, poz. 389. 
mysłowym ${ }^{18}$. Przedmiotowa ustawa uchylała zmiany wprowadzone w systemie poboru podatku przemysłowego podczas wojny na terenach okupowanych przez Niemcy i Austrię. Zgodnie z art. 2 na całym obszarze byłego zaboru rosyjskiego stosowana była rosyjska ustawa o podatku przemysłowym z $1898 \mathrm{r}$. w brzmieniu z 1903 r. wraz z nowelizacjami z 4 października 1914 r., 9 stycznia 1915 r., z jednoczesnym uchyleniem zawartych w tych nowelach ograniczeń co do czasu trwania ich mocy obowiązującej. Do ustawy z 1920 r. wydano dwa rozporządzenia wykonawcze, które uzupełniły jej treść ${ }^{19}$. Następnym krokiem było rozciągnięcie obowiązywania ustawy na obszar całego kraju, począwszy od roku podatkowego $1921^{20}$.

Ustawa z 1920 r. stanowiła rozwiązanie tymczasowe. Ostateczne zasady poboru podatku przemysłowego kształtowały się w latach 1922-1925. Był to okres, kiedy wprowadzono rozwiązania podatkowe nakierowane jedynie na osiągniecie celu fiskalnego przez państwo, szczególnie w kontekście przeprowadzonej reformy walutowej mającej na celu ograniczenie inflacji. Powyższe założenia wpłynęły na kształt pierwszej jednolitej ustawy z dnia 14 maja $1923 \mathrm{r}$. w przedmiocie państwowego podatku przemysłowego ${ }^{21}$, która uchy-

18 Ustawa z dnia 6 lipca 1920 r. w przedmiocie ujednostajnienia na obszarze byłego zaboru rosyjskiego ustaw i rozporządzeń o podatku przemysłowym, Dz.U. nr 66, poz. 437.

19 Rozporządzenie Ministra Skarbu z 10 grudnia 1920 r. wydane w porozumieniu z Ministrem Kolei Żelaznych w przedmiocie ustalenia głównych i bocznych linii kolejowych do celów wymiaru podatku przemysłowego na obszarze byłego zaboru rosyjskiego, Dz.U. 1921, nr 3, poz. 14; Rozporządzenie Ministra Skarbu z 10 grudnia 1920 r. w przedmiocie wykonania ustawy z 6 lipca 1920 r. o ujednostajnieniu na obszarze byłego zaboru rosyjskiego ustaw i rozporządzeń o podatku przemysłowym, Dz.U. 1921, nr 1, poz. 1.

20 Ustawa z 17 grudnia 1921 r. w przedmiocie rozciągnięcia mocy obowiązującej ustawy z 6 lipca 1920 r. o ujednostajnieniu na obszarze byłego zaboru rosyjskiego ustaw i rozporządzeń o państwowym podatku przemysłowym na cały obszar Rzeczypospolitej Polskiej, Dz.U. 1922, nr 2, poz. 7. Zob. też. P. Grata, Polityka podatkowa II Rzeczypospolitej. Zarys problematyki, „Rocznik Dziejów Społecznych i Ekonomicznych” 2012, t. 72, s. 135.

21 Dz.U. 1923, nr 58, poz. 412. Uzupełnione: Rozporządzenie Ministra Skarbu z 27 czerwca 1923 r. w celu wykona- lała wszelkie przepisy dzielnicowe i obowiązywała na terenie całego kraju, w tym również w górnośląskiej części województwa śląskiego ${ }^{22}$.

Niestety powyższa ustawa ujawniła i ugruntowała największe słabości w konstrukcji podatku przemysłowego, które odbijały się negatywnie na jego formule przez całe dwudziestolecie międzywojenne. Błędem okazało się oparcie na rosyjskich rozwiązaniach, gdzie wysokość pobieranego podatku nie odzwierciedlała faktycznie uzyskiwanych dochodów, oraz pobieranie go w dwóch formach, tj. świadectwa przemysłowego ${ }^{23}$ (podatek zasadniczy) oraz podatku dodatkowego od obrotu $^{24}$.

Przyjęta konstrukcja podatku przemysłowego w ustawie z 1923 r. całkowicie pomijała aspekt efektywności ekonomicznej przedsiębiorstwa, wysuwając na pierwszy plan cel fiskalny, a zarazem ignorując aspekty regulacyjny i stymulacyjny ${ }^{25}$. W zamyśle auto-

nia ustawy z 14 maja 1923 r. w przedmiocie państwowego podatku przemysłowego, Dz.U. nr 67, poz. 522.

22 Przepisy ustawy rozciągnięto na obszar województwa śląskiego na mocy Rozporządzenia Ministra Skarbu z 31 lipca 1924 r. w celu wykonania ustawy z 9 lipca 1924 r. o rozciągnięciu mocy obowiązującej: a) ustawy z 14 maja 1923 r. w przedmiocie państwowego podatku przemysłowego; b) ustawy z 16 lipca 1920 r. o opłacie stemplowej od sprzedaży przedmiotów zbytku na górnośląską część województwa śląskiego, Dz.U. nr 71, poz. 693.

23 Niejednokrotnie świadectwo przemysłowe stawało się swoistym certyfikatem przemysłowym potwierdzającym fakt zarejestrowania spółki, gdyż nowo powstałe przedsiębiorstwo uzyskiwało je w ciągu kilku godzin od złożenia wniosku. Zob. Nowopowstające firmy a podatek przemysłowy, „Czasopismo Skarbowe” 1931, nr 6, s. 328. Historycznie źródeł instytucji świadectwa przemysłowego należy doszukiwać się w pogłównym, jako swoistej opłaty za pozwolenie wykonywania zawodu. R. Rybarski, Nauka skarbowości, Warszawa 1935, s. 260.

24 System rosyjski był natomiast wzorowany na francuskim systemie patentowym. Po I wojnie światowej podatek obrotowy został wprowadzony niemal w całej Europie, zob. S. Głąbiński, Polskie prawo skarbowe, Lwów 1928, s. 55.

$25 \mathrm{~W}$ art. 11 ustawy z 1920 r. przewidziano jeszcze podatek od kapitału przedsiębiorstw, który wynosił 0,5\% od 100 marek kapitału zakładowego. Co ważne, na poczet podatku dodatkowego zaliczano kwoty zapłacone, a wynikające z opła- 
rów projektu ustawy połączenie podatku od obrotu z podatkiem od przychodu z przemysłu i handlu miało odjąć podatkowi od obrotu cechy obciążające głównie konsumentów. Spowodowało to, że nadano mu cechy ciężaru podatkowego - tak dla producenta, jak dla podmiotu handlowego ${ }^{26}$.

Nabywając świadectwo przemysłowe za niewysoką cenę, przedsiębiorca dokonywał pewnego rodzaju przedpłaty, później zaś zobowiązany był do dopłaty, cony przez przedsiębiorców był realny i sprawiedliwy wobec przyjęcia jednolitej stawki podatku od obrotu w wysokości $2 \%^{28}$.

\section{Okres poinflacyjny i okres ożywienia gospodarczego}

Ze względu na potrzeby budżetu państwa dokonano zmian w zakresie sposobu opłacania podatku przemysłowego na mocy Ustawy z dnia 11 stycznia

\section{Błędem okazało się oparcie na rosyjskich} rozwiązaniach, gdzie wysokość pobieranego podatku nie odzwierciedlała faktycznie uzyskiwanych dochodów, oraz pobieranie go w dwóch formach: świadectwa przemysłowego oraz podatku dodatkowego od obrotu.

która stanowiła różnicę pomiędzy kwotą podatku od obrotu a przedpłatą uiszczoną za świadectwo przemysłowe ${ }^{27}$. Chroniło to budżet państwa przed utratą wartości pieniądza, jednocześnie zaś podatek pła-

cenia zasadniczego podatku przemysłowego. Obowiązek zapłaty podatku od zysku obciążał przedsiębiorców, gdy zysk netto przekroczył 3\% kapitału zakładowego, przy czym fakt opłacania podatku od zysku nie zwalniał z opłacania zasadniczego podatku i podatku od kapitału. Zob. L. Ćwikła, Prawne aspekty rozwoju turystyki w Polsce w latach 1918-1939, Lublin 2011; recenzja: A. Witkowski, L. Ćwikła, „Prawne aspekty rozwoju turystyki w Polsce w latach 1918-1939", Lublin 2011, „Administracja. Teoria - Dydaktyka - Praktyka” 2012, nr 27, s. 195; zob. też: A. Witkowski, Podatek obrotowy w Polsce międzywojennej, „Zamojskie Studia i Materiały” 2005, z. 3(18), s. 268-269.

26 O systemie danin publicznych $w$ Polsce. Prace o charakterze ogólnym, z. 3, Warszawa 1926, s. 45-46; W. Bernhardt, Polityka podatkowa, „Czasopismo Skarbowe” 1931, nr 8, s. 436.

27 Reforma Podatku Przemysłowego, "Czasopismo Skarbowe” 1930, nr 3, s. 130.
1924 r. o naprawie Skarbu Państwa i reformie walutowej $^{29}$, zgodnie z którą postanowiono nie naliczać na podatek przemysłowy przedpłat uiszczonych na poczet tego podatku w postaci świadectw przemysłowych. Zerwano tym samym z konstrukcją świadectwa przemysłowego jako swoistej przedpłaty na poczet przyszłego zobowiązania ${ }^{30}$. Jednocześnie podniesiono jego wymiar przez podwyżkę opłat za świadectwa przemysłowe ${ }^{31}$. Rozwiązanie to określiło nowy sposób opłacania podatku przemysłowego, który od

28 K. Ostrowski, Polityka finansowa Polski przedwrześniowej, Warszawa 1958, s. 79.

29 Ustawa z dnia 11 stycznia 1924 r. o naprawie Skarbu Państwa i reformie walutowej, Dz.U. nr 4, poz. 28.

30 Rozporządzenie Prezydenta Rzeczypospolitej z dnia 31 stycznia 1924 r. w przedmiocie niezaliczania na podatek przemysłowy przedpłat, uiszczonych na poczet tegoż podatku w postaci świadectw przemysłowych, Dz.U. nr 12, poz. 102.

31 Rozporządzenie Prezydenta Rzeczypospolitej Polskiej z dnia 12 kwietnia 1924 r. o podwyższeniu ceny świadectw przemysłowych i kart rejestracyjnych, Dz.U. nr 33, poz. 340. 
tej pory przyjął dwojaką formę: opłaty za świadectwo przemysłowe i podatku od obrotu ${ }^{32}$.

Należy wspomnieć, że pomimo podwyżek podatku przemysłowego przyjęta zasada połączenia podatku przychodowego z podatkiem od obrotu przynosiła mizerne rezultaty finansowe. Podatnicy powszechnie uchylali się od ich płacenia albo z nim zwlekali, co przy postępującej deprecjacji pieniądza stwarzało szczególnie korzystną sytuację dla podmiotu opłacającego podatek. Zwłoka prowadziła bowiem do faktycznego zmniejszenia zobowiązania podatkowego, co przekładało się bezpośrednio na niższe wpływy do budżetu państwa. W 1924 r. wobec lawinowej inflacji wprowadzono kary za każdy dzień zwłoki zapłaty podatku w wysokości $0,5 \%$ jego wymiaru ${ }^{33}$.

W latach 1924-1925 ustabilizowano inflację i wartość waluty, jednocześnie zaś doszło do ujawnienia spustoszeń, jakich inflacja dokonała w majątkach przedsiębiorstw. Nastąpiła redukcja ich kapitałów, zmianie uległ także stosunek między kapitałami trwałymi a obrotowymi - na niekorzyść tych drugich. Paradoksalnie ustabilizowanie pieniądza i wzrost jego wartości w stosunku do walut innych państw przyczyniły się do stagnacji gospodarczej przez zapaść w eksporcie, który był niezbędny dla funkcjonowania przedsiębiorstw.

Państwo stanęło przed zadaniem zniwelowania tych negatywnych skutków. Musiało aktywnie wpłynąć na politykę podatkową, tym bardziej że wprowadzone wcześniej podwyżki wymiaru podatków bezpośrednich były bardzo odczuwalne. Zauważył to ówczesny minister Władysław Grabski. Dążył on do wprowadzenia systemu podatkowego, w którym dana grupa społeczna będzie płacić podatki proporcjonalne do swych możliwości, a system podatkowy oparty na stałej podstawie dochodowej, tj. możliwie najszerszej grupie podatników płacących podatki o umiarkowanej wysokości, zapewni stałe przychody budżetowi państwa. Niestety ostatecznie nie doszło do redukcji obciążeń podatkowych, ale do ich przesunięcia na grupy dotychczas zwolnione $\mathrm{z}$ ich

32 R. Rybarski, Nauka skarbowości, s. 260.

33 Rozporządzenie Prezydenta Rzeczypospolitej z dnia 16 lutego 1924 r. o podniesieniu stawek podatków bezpośrednich, Dz.U. nr 16, poz. 151. opłacania; dokonano także podwyższenia podatków pośrednich ${ }^{34}$.

Ustawa z 1923 r. przetrwała jedynie rok, gdyż 1 stycznia 1926 r. weszła w życie ustawa z dnia 15 lipca 1925 r. o państwowym podatku przemysłowym ${ }^{35}$, pobieranym od wszystkich przedsiębiorstw i zajęć $\mathrm{w}$ formie świadectw przemysłowych oraz w postaci podatku od obrotu. Jakkolwiek wejście w życie tej ustawy zakończyło proces unifikacji zasad poboru i wymiaru podatku przemysłowego dla całego państwa ${ }^{36}$, to ustawę tę należy uznać raczej za nowelizację poprzedzającego ją aktu prawnego. To, co odróżniało ją od poprzedniej regulacji, to przede wszystkim zdywersyfikowanie i obniżenie stawek podatku od obrotu, które wahały się od 0,5\% (stawka preferencyjna ${ }^{37}$ ) do $5 \%$ i były uzależnione od rodzaju przedsiębiorstwa oraz prowadzonej działalności. Jako stawkę podstawową pozostawiono $2 \%$. Wymaga podkreślenia, że niejednokrotnie wysokość tego podatku uzależniona była również od kategorii opłacanego świadectwa przemysłowego.

Wejście w życie nowej ustawy spotkało się z dużą krytyką. Utrzymano mechaniczne połączenie bezpośredniego podatku przychodowego z podatkiem obrotowym. Prowadziło to do nierównomierności w obciążeniach podatkowych z uwagi na fakt, że cena wykupu świadectwa przemysłowego została oparta na funkcji przychodowej i cechach zewnętrznych przedsiębiorstwa bez odniesienia jego wymiaru do dochodów. Wymiar nie uwzględniał zdolności płatniczych podatnika i rentowności danego przedsiębiorstwa. Tym bardziej - co było przedmiotem największej krytyki że nie następowała żadna korekta podatku przychodowego w odniesieniu do kryterium dochodowego, jak to miało miejsce np. w ustawie rosyjskiej ${ }^{38}$.

34 Z. Landau, J. Tomaszewski, Gospodarka Polski międzywojennej 1918-1939, t. 2: 1924-1929, Warszawa 1982, s. 127-128.

35 Dz.U. 1925, nr 79, poz. 550, obowiązująca od 1 stycznia $1926 \mathrm{r}$.

36 P. Grata, Polityka podatkowa..., s. 144.

37 Płatnik podatku przemysłowego od obrotu nie był ograniczony w wyborze środków dowodowych w celu wykazania wymogów zastosowania ulgowej stawki w wysokości 1,2\%, zob. Wyrok Najwyższego Trybunału Administracyjnego z 25 lutego 1931 r., l. rej. 1940/29.

38 O systemie danin publicznych $w$ Polsce, s. 46. 
Przez wprowadzenie preferencyjnej stawki podatku od obrotu dokonano uprzywilejowania dużych przedsiębiorstw kosztem instytucji finansowych oraz małych przedsiębiorstw. Usunięto także opodatkowanie wewnętrzne obrotów, czym umożliwiono instytucjom kredytowym uwzględnienie strat przy ustalaniu podstawy opodatkowania ${ }^{39}$. Szczególną pozycję uzyskali eksporterzy, którzy w przypadkach uzasadnionych gospodarczo mogli wystąpić do ministra skarbu o bonifikatę podatku uiszczonego od obrotu z dostawy części składowych oraz materiałów pomocniczych użytych do produkcji towarów przeznaczonych na eksport ${ }^{40}$.

Zgodnie ustawą o podatku przemysłowym państwowemu podatkowi pobieranemu $\mathrm{w}$ formie świadectwa przemysłowego oraz podatku od obrotu podlegały wszelkie handlowe ${ }^{41}$, przemysłowe oraz pozostałe przedsiębiorstwa prowadzące działalność w celach zarobkowych oraz zajęcia przemysłowe wymienione w taryfie do ustawy ${ }^{42}$, a także wolne zawody, z wyłączeniem typów działalności określonych w ustawie ${ }^{43}$.

39 J. Kaliski, Dawne i nowe wątpliwości przy stosowaniu ustawy o podatku przemysłowym, „Przegląd Prawa Handlowego” 1927, s. 258.

40 Ulgi w podatku przemysłowym dla eksportu, „Czasopismo Skarbowe" 1929, nr 11-12, s. 322; Ulgi w podatku przemystowym dla eksportu, „Przegląd Skarbowy” 1929, z. 12, s. 1-7.

41 Wymieniając przedsiębiorstwa handlowe, ustawodawca odnosił się do tych prowadzących działalność detaliczną i hurtową, przy czym do ustawy nie wprowadzono definicji handlu hurtowego, co przysparzało organom skarbowym problemów w zakresie wymiaru podatku od obrotu, zob. F. Świtalski, Handel hurtowy w świetle ustawy o państwowym podatku przemysłowym, „Czasopismo Skarbowe” 1930, nr 4, s. 173-80; J. Lubowicki, Pojęcie sprzedaży hurtowej, "Przegląd Skarbowy” 1931, z. 6-7, s. 145-147.

42 Integralną częścią ustawy był załącznik taryf zawierający podział miejscowości na klasy, a przedsiębiorstw i zajęć na kategorie oraz podający ceny świadectw przemysłowych.

43 Państwowemu podatkowi przemysłowemu nie podlegały: 1) gospodarstwa rolne i leśne; 2) sprzedaż i dostawa towarów pochodzących $\mathrm{z}$ własnego gospodarstwa rolnego oraz własnego gospodarstwa leśnego; 3) eksploatowanie w obrębie własnych lub dzierżawionych gruntów: pokładów torfu, piasku, wapna, kamieni, kredy, fosforytów i tym podobnych wyłącznie na potrzeby własnego gospodarstwa; 4) młyny
Przepis ten od samego początku swego obowiązywania budził spore trudności interpretacyjne, gdyż przedsiębiorstwo w rozumieniu ustawy o podatku przemysłowym nie pokrywało się z pojęciem przedsiębiorstwa w znaczeniu prawa cywilnego, tym bardziej że nie istniała legalna definicja przedsiębiorstwa. Powodowało to, że przedsiębiorca mógł być zobowiązany do wykupienia świadectwa przemysłowego dla każdego rodzaju prowadzonej działalności, co wiązało się później z obowiązkiem zapłaty podatku od obrotu od różnych podstaw wymiarowych ${ }^{44}$. Lukę w tym zakresie próbowały uzupełnić nauka i judykatura ${ }^{45}$.

i tartaki znajdujące się w obrębie własnych lub dzierżawionych gruntów, a zaspokajające wyłącznie potrzeby gospodarcze właścicieli, względnie dzierżawców tych gruntów. Co jednak ciekawe i wymaga zaznaczenia, utrzymywanie oddzielnego składu poza obrębem własnych gruntów wykluczało zwolnienie od podatku przemysłowego od sprzedaży i dostawy wytworów własnej produkcji również w sytuacji, gdy skład utrzymywany był tylko czasowo i służył jedynie do ładowania do wagonów drewna już sprzedanego. Wyrok Najwyższego Trybunału Administracyjnego z 15 kwietnia 1931 r., 1. rej. 2177/29.

44 I. Weinfeld, Skarbowość polska, Warszawa 1935, s. 179. Zob. też: K. Lipiński, Określenie oddzielnych zakładów i przedsiębiorstw w podatku przemysłowym, „Czasopismo Skarbowe” 1930, nr 10, s. 492-494; A. Alland, Podatek przemysłowy od komisu, agentury i pośrednictwa, „Czasopismo Skarbowe” 1926, nr 4, s. 8.

45 Przedsiębiorstwem w rozumieniu ustawy był każdy zespół działalności gospodarczej skierowany na osiągnięcie jednego z celów gospodarczych wymienionych w ustawie (wyrok Najwyższego Trybunału Administracyjnego z 28 kwietnia 1933 r., 1. rej. 2999/31). Za przedsiębiorstwo przemysłowe uważano przedsiębiorstwo wytwarzające lub przetwarzające (wyrok Najwyższego Trybunału Administracyjnego z 13 grudnia 1934 r., 1. rej. 5856/32). Ustawa nie wyszczególniała przedsiębiorstw podlegających podatkowi przemysłowemu, wobec czego każde przedsiębiorstwo podpadające pod pojęcie handlowego lub przemysłowego, nawet jeśli nie było wymienione w taryfie, wykonywane samoistnie i zawodowo, stanowiło przedmiot podatku przemysłowego (wyrok Sądu Najwyższego z 18 maja 1932 r., II K 90/32). Ustawa przewidywała jedynie opodatkowanie przedsiębiorstw handlowych i przemysłowych prowadzonych z góry powziętym przez przedsiębiorcę zamiarem, by stworzyć z niego źródło dochodu (wyrok Najwyższego Trybunału Administracyjnego 


\section{Zgodnie z ustawą o podatku przemysłowym}

\section{państwowemu podatkowi pobieranemu w formie świadectwa przemysłowego oraz podatku od obrotu podlegały wszelkie handlowe, przemysłowe} oraz pozostałe przedsiębiorstwa prowadzące działalność w celach zarobkowych oraz zajęcia przemysłowe wymienione w taryfie do ustawy.

Za podstawę do obliczenia podatku przemysłowego od obrotu, zgodnie z art. 4 i 5, służył obrót osiągnięty przez przedsiębiorstwo, który stanowił sumę przychodu brutto ${ }^{46}$. Zasada ta odnosiła się jednak wyłącznie do przedsiębiorstw handlowych. W przypadku np. instytucji kredytowych była to suma pobranych prowizji oraz zysk brutto $\mathrm{z}$ operacji walutami. W stosunku do zajęć przemysłowych i wolnych zawodów podstawą był znów zarobek brutto, które w praktyce

z 25 października 1933 r., l. rej. 3371/32). Ustawodawstwo podatkowe obciążało podatkiem przemysłowym tylko takie przedsiębiorstwa, które w podmiotowym znaczeniu były połączone z działalnością w celu zarobkowym, działalnością obliczoną na zysk, przy czym zarobek nie musiał być osiągnięty (orzeczenie Sądu Najwyższego z 28 stycznia 1936 r., K 1113/35). Przedsiębiorstwem w rozumieniu ustawy był każdy zespół działalności gospodarczej skierowany na osiągnięcie jednego z celów gospodarczych wymienionych w ustawie. Zob. wyrok Najwyższego Trybunału Administracyjnego z 28 kwietnia 1933 r., l. rej. 2999/31; B. Hasfeld (oprac.), Orzecznictwo podatkowe Najwyższego Trybunału Administracyjnego i Sądu Najwyższego 1924-1936 r. Podatek dochodowy, podatek przemysłowy, ordynacja podatkowa, Warszawa 1937, s. 190-204, 197-198.

46 S. Głąbiński, Polskie prawo..., s. 57; A. Franz, Reasumpcje wymiarów i dodatkowe wymiary państwowego podatku przemysłowego od obrotu, „Czasopismo Skarbowe” 1928, nr 3, s. 73-77; A. Alland, Zasady opodatkowania skupu, uprawianego zawodowo, w celu sprzedaży, „Czasopismo Skarbowe" 1928, nr 3, s. 77-81. było szerszym pojęciem i oznaczało sumę przychodu gotówkowego i zakredytowanego, przy uznaniu za obrót sumy transakcji, bez względu na sposób oraz czas zapłaty. Innym razem ustawa definiowała zarobek netto jako faktycznie pobrane wynagrodzenie ${ }^{47}$.

Świadectwa przemysłowe nabywano w listopadzie lub grudniu na następny rok podatkowy ${ }^{48}$. Przedsię-

47 Firma zagraniczna, która na zasadzie umowy zawartej z przedsiębiorstwem krajowym dostarczała maszyny i dokonywała ich montażu w budowanym dla tego przedsiębiorstwa zakładzie przemysłowym oraz nadzorowała budowę za pośrednictwem utworzonego w kraju oddziału, miała obowiązek wykupienia świadectwa przemysłowego dla przedsiębiorstwa robót i dostaw. Zob. Wyrok Najwyższego Trybunału Administracyjnego z 15 marca 1933 r., l. rej. $10248 / 31$.

48 Jedynie w formie świadectw przemysłowych podatek przemysłowy był opłacany od przedsiębiorstw handlu wędrownego oraz jarmarcznego oraz przemysłu bez stałej siedziby, przedsiębiorstw prowadzących wydawnictwa dzienników i innych pism periodycznych, rzemieślników czy dorożkarzy. W postaci jedynie podatku od obrotu podatek był opłacany przez samodzielne wolne zawody. Do grona wolnych zawodów ustawodawca zaliczył również inżynierów, jednak prowadzenie budowy przez inżyniera w tak zwanym stosunku gospodarczym, który obejmował również nabywanie materiałów budowlanych w imieniu własnym, lecz na rachunek zleceniodawcy, nie mieściło się w granicach wykonywania wolnego zawodu i rodziło obowiązek posiadania świadectwa przemysłowego. Zob. Wyrok Najwyższego 
biorstwa zakładane w trakcie roku podatkowego lub rozpoczynające działalność gospodarczą przed 1 lipca były obowiązane do nabycia świadectwa rocznego jeszcze przed rozpoczęciem działalności. Jeżeli rozpoczęcie działalności nastąpiło przed 1 lipca, należało wykupić świadectwo półroczne. Brak świadectwa był karany grzywną ${ }^{49}$.

Przedsiębiorcy opłacający podatek przemysłowy byli wielokrotnie obligowani do opłacania dodatku nadzwyczajnego w celu poprawy stanu budżetu państwa. W pierwszej kolejności 10-procentowy dodatek wprowadzono w 1926 r., przy czym miał on obowiązywać jedynie przez rok. Na podstawie ustawy z 12 lutego 1931 r. stał się jednak dodatkiem stałym ${ }^{50}$. W 1935 r. wysokość dodatku zwiększono z $10 \%$ do $15 \%{ }^{51}$. Ostatecznie pobór dodatku uchylono w 1936 r. $^{52}$

Trybunału Administracyjnego z 6 października 1930 r., l. rej. 47/28; Podatek przemysłowy, „Informator Podatkowy” 1928, cz. 2, s. 34-35.

49 Karyza nieposiadanie świadectw przemysłowych, „Przegląd Skarbowy" 1926, z. 8, s. 239

50 Ustawa $\mathrm{z}$ dnia 12 lutego $1931 \mathrm{r}$. o poborze $10 \%$ dodatku do niektórych podatków i opłat stemplowych, Dz.U. nr 16, poz. 82; Rozporządzenie Ministra Skarbu z 6 marca 1931 r. w sprawie poboru $10 \%$ dodatku do niektórych podatków i opłat stemplowych, Dz.U. nr 23, poz. 138.

51 Ustawa z dnia 26 marca 1935 r. o poborze $10 \%$ dodatku do opłat stemplowych i podatków pośrednich oraz 15\% dodatku do podatków bezpośrednich oraz spadkowego i od darowizn, Dz.U. nr 22, poz. 127; Rozporządzenie Ministra Skarbu z 30 marca 1935 r. o poborze $10 \%$ dodatku do opłat stemplowych, podatków pośrednich i podatku gruntowego oraz 15\% dodatku do podatków bezpośrednich oraz spadkowego i od darowizn, Dz.U. nr 23, poz. 155; okólnik Ministerstwa Skarbu z 17 października 1935 r. w sprawie nabywania świadectw przemysłowych na rok 1936, Dz.Urz.M.S. nr 29, poz. 660; Okólnik Ministerstwa Skarbu z 23 października 1936 r. w sprawie nabywania świadectw przemysłowych na rok 1937, Dz.Urz.M.S. nr 29, poz. 891; Okólnik Ministerstwa Skarbu z 20 października 1937 r. w sprawie nabywania świadectw przemysłowych na rok 1938, Dz.Urz.M.S. nr 28, poz. 841 .

52 Dekret Prezydenta Rzeczypospolitej z 14 stycznia 1936 r. w sprawie zmiany niektórych przepisów, dotyczących państwowego podatku przemysłowego i opłat stemplowych, Dz.U. nr 3, poz. 15.
Lata 1926-1929 zwykle nazywa się okresem ożywienia gospodarczego. Niestety osiągane wówczas nadwyżki budżetowe prowadziły do rozluźnienia reżimu podatkowego przyjętego w poprzednich latach, kiedy dobra koniunktura gospodarcza zapewniała stałe i wysokie wpływy do budżetu państwa. Koniunktura ta potencjalnie pozwalała na wprowadzenie oczekiwanych reform podatku przemysłowego, które w dłuższej perspektywie zapewniłby większe wpływy budżetowe. Ustawodawca zaniechał jednak reform, a jednocześnie uległ określonym grupom interesu, które uzyskały wybrane preferencje podatkowe. Na przykład na podstawie ustawy o popieraniu przemysłu cynkowego ${ }^{53}$ umorzono zaległości podatkowe amerykańskiemu koncernowi Harimana. Ustawa została uchylona w 1928 r., jednak jej konsekwencje były odczuwalne do roku 1939, gdyż stworzyła ona w Polsce swoisty monopol cynkowy ${ }^{54}$.

W omawianym okresie wprowadzono także przepisy mające uatrakcyjnić rozpoczęcie działalności gospodarczej w Gdyni czy przeniesienie tam siedziby, co miało związek z prowadzoną wówczas rozbudową tego miasta. 1 czerwca 1927 r. prezydent wydał rozporządzenie o popieraniu rozbudowy i rozwoju gospodarczego miasta Gdyni ${ }^{55}$, która przewidywała wiele zwolnień od podatków i opłat związanych z zakładaniem i rozwijaniem przedsiębiorstw, w tym 15-letni okres zwolnienia od podatku przemysłowego - pod warunkiem, że siedziba danego podatnika znajdowała się w Gdyni, a jego działalność przyczyniała się do rozwoju gospodarczego miasta ${ }^{56}$.

53 Ustawa z dnia 30 kwietnia 1926 r. o popieraniu przemysłu cynkowego, Dz.U. nr 49, poz. 292.

54 Rozporządzenie Prezydenta Rzeczypospolitej z dnia 6 marca 1928 r. o uchyleniu ustawy z dnia 30 kwietnia 1926 r. o popieraniu przemysłu cynkowego, Dz.U. nr 26, poz. 235.

55 Rozporządzenie Prezydenta Rzeczypospolitej z dnia 1 czerwca 1927 r. o popieraniu rozbudowy i rozwoju gospodarczego miasta i portu Gdyni, Dz.U. nr 51, poz. 452.

56 Podobne preferencje podatkowe uzyskali również przedsiębiorcy inwestujący w elektryfikację, której upowszechnienie było priorytetem rządu, zob. Rozporządzenie Prezydenta Rzeczypospolitej z dnia 27 października 1933 r. o popieraniu elektryfikacji, Dz.U. nr 85, poz. 633. 


\section{Okres wielkiego kryzysu i pokryzysowej aktywności gospodarczej}

Sytuacja budżetowa państwa polskiego uległa diametralnej zmianie wraz z nadejściem do Polski tzw. wielkiego kryzysu. Niestety państwo nie było na niego przygotowane. Pogarszająca się sytuacja budżetowa wymuszała podejmowanie nadzwyczajnych działań w zakresie polityki podatkowej, co miało na celu zapewnienie wpływów do budżetu państwa na poziome umożliwiającym realizację podstawowych zadań. Wiązało się to ze wzrostem obciążeń podatkowych czy wprowadzaniem licznych danin o charakterze nadzwyczajnym. Jednocześnie wprowadzono mechanizmy mające pobudzać aktywność gospodarczą przedsiębiorców, co miało wpłynąć na wzrost wpływów budżetowych. Jak czytamy w „Czasopiśmie Skarbowym” z 1930 r., przez obniżkę podatku od obrotu ustawodawca postanowił ułatwić i usprawnić wymianę towarową, a w ten sposób przyczynić się do wzrostu kapitałów przedsiębiorstw i obniżki cen towarów. Przyjęte rozwiązanie miało ograniczyć negatywne skutki kryzysu finansowego, niestety jak czytamy, ustawodawca w swoich rozwiązanych był bardziej zachowawczy niż w innych krajach ${ }^{57}$.

$\mathrm{Na}$ mocy noweli rozszerzono katalog podmiotowych zwolnień podatkowych oraz zmniejszono stawki opodatkowania ${ }^{58}$. Dla mniejszych przedsiębiorstw przemysłowych i handlowych, poczynając od $1932 \mathrm{r}$., wprowadzono formę ryczałtową poboru podatku przemysłowego ${ }^{59}$. Zryczałtowane stawki może uprościły pobór tego podatku, jednak dane wyjściowe co do jego wysokości były określane na podstawie szacunków z poprzednich lat, co w okresie kryzysu nie odzwierciedlało aktualnej sytuacji finansowej przedsiębiorców. Realnie doszło zatem do zwyżki obciążeń podatkowych, a nie ich obniżki.

57 Reforma Podatku Przemysłowego, „Czasopismo Skarbowe” 1930, nr 3, s. 134-136.

58 Ustawa z dnia 19 grudnia 1931 r. w sprawie zmiany ustawy z dnia 15 lipca 1925 r. o państwowym podatku przemysłowym, Dz.U. nr 112, poz. 881.

59 System zryczałtowanego podatku uprościł jego wymiar tylko dla 173 tysięcy płatników, czyli około 34\% ogółu płatników podatku obrotowego, zob. J. Lubowicki, Uproszczony wymiar podatku obrotowego, „Czasopismo Skarbowe” 1933, nr 9, s. 358 .
Jednocześnie upoważniono ministra skarbu do wprowadzenia scalonego podatku przemysłowego od wszystkich obrotów danym artykułem. Scalony podatek był pobierany raz w pierwszej fazie obrotu (u producenta) według stawki odpowiednio podwyższonej, mającej skompensować niepobieranie podatku w dalszych fazach obrotu. Scalony podatek był faktycznie akcyzą i pobierano go od tych samych artykułów, które były objęte akcyzą, co było dodatkowym opodatkowaniem od spożycia i odnosiło się do produktów monopolowych ${ }^{60}$.

Pomimo podejmowanych działań mających zwiększyć wpływy z podatku przemysłowego na początku roku budżetowego 1932/1933 zaległości w podatkach przemysłowym i dochodowym przekroczyły kwotę 500 milionów złotych. Skłoniło to ustawodawcę do wprowadzenia mechanizmu dającego podatnikom możliwość zmniejszenia swoich zobowiązań przez wystąpienie o umorzenie $50 \%$ zaległości podatkowych, przy jednoczesnym zapewnieniu o zapłaceniu pozostałej części zaległego podatku ${ }^{61}$.

W 1931 r. nastąpiła likwidacja podatku majątkowego pobieranego od 1923 r. Aby ratować doraźnie budżet państwa, w miejsce podatku majątkowego wprowadzono nadzwyczajną daninę majątkową na podstawie ustawy z 24 marca 1933 r. $^{62}$ Obowiązywała ona przedsiębiorców opłacających podatek obrotowy oraz podatek od nieruchomości w latach 1933-1937. Zgodnie z postanowieniami art. 2 ustawy z $1933 \mathrm{r}$. wznowiono tym samym podatek majątkowy na okres pięciu lat, zakładając ściągniecie 24 milionów złotych rocznie. Płatników podzielono na trzy grupy kontyngentowe; płatnicy podatku przemysłowego stanowili II grupę, która miała zapłacić 10,5 miliona złotych rocznie. Wprowadzono także opodatkowanie nadzwyczajne niektórych zajęć zarobkowych ${ }^{63}$ oraz uchwalono pobór dodatku do podatku przemysłowego

60 K. Ostrowski, Polityka finansowa..., s. 188.

61 Ustawa z dnia 10 marca 1932 r. o spłacie zaległości podatkowych, Dz.U. nr 29, poz. 291.

62 Ustawa z dnia 24 marca 1933 r. o nadzwyczajnej daninie majątkowej, Dz.U. nr 29, poz. 248.

63 Ustawa $z$ dnia 19 grudnia 1931 r. o nadzwyczajnym podatku od niektórych zajęć zawodowych, Dz.U. nr 112, poz. 882. 
w wysokości $10 \%$ obrotów osiąganych przez przedsiębiorstwa przemysłowe ${ }^{64}$.

Lata 1935-1939 to okres zmniejszania obciążeń podatkowych przedsiębiorstw i eliminowania z systemu podatkowego swoistych przybudówek wprowadzonych w okresie wielkiego kryzysu, a mających zapewnić stałe wpływy budżetowe. Uproszczono wówczas pobór podatku przemysłowego i zniesiono nadzwyczajną daninę majątkową wprowadzoną w $1933 \mathrm{r}^{65}$ Szczególne uprawnienia przyznano przedsiębiorstwom inwestującym w Centralnym Okręgu Przemysłowym, czyli tzw. trójkącie bezpieczeństwa ${ }^{66}$. Uzyskali oni zwolnienia od opłacania podatku przemysłowego na okres od 10 do 15 lat $^{67}$.

Próby zracjonalizowania systemu poboru podatku przemysłowego i zerwania z zasadą nierównomierności tego podatku, oparcia się na cechach zewnętrznych przedsiębiorstwa czy wreszcie zerwania $\mathrm{z}$ mechanicznym połączeniem świadectw przemysłowych i podatku od obrotu zostały zrealizowane dopiero na mocy ustawy z 4 maja 1938 r. o podatku obrotowym $^{68}$. Reforma podatkowa była rezultatem długo oczekiwanych przez przedsiębiorców zmian systemu podatkowego, przede wszystkim w zakresie podatku przemysłowego.

W pierwszej kolejności zlikwidowano świadectwa przemysłowe, czyli ostatecznie zerwano z zasadą połączenia podatku przychodowego z obrotowym, pozostawiając jedynie ten drugi ${ }^{69}$. To, co jednak najistotniejsze,

64 Rozporządzenie Prezydenta Rzeczypospolitej z dnia 27 października 1933 r. o poborze $10 \%$ dodatku do państwowego podatku gruntowego i przemysłowego, Dz.U. nr 84, poz. 612.

65 Dekret Prezydenta Rzeczypospolitej z dnia 14 stycznia 1936 r. w sprawie zmiany niektórych przepisów, dotyczących państwowego podatku przemysłowego i opłat stemplowych, Dz.U. nr 3 poz. 15.

66 Od północy granice wyznaczała rzeka Wieprz do ujścia z Wisłą, na zachodzie Dęblin, na wschodzie rzeka Wieprz do Zwierzyńca, od południa linia kolejowa Nowy Sącz-Chyrów.

67 Rozporządzenie Prezydenta Rzeczypospolitej z dnia 22 marca 1928 r. w sprawie ulg dla przedsiębiorstw przemysłowych i komunikacyjnych, Dz.U. nr 36, poz. 329.

68 Dz.U. 1938, nr 34, poz. 292.

69 Por. W. Ślifirczyk, Wykonanie, niewykonanie i nienależyte wykonanie zobowiązania podatkowego, Warszawa 2018 , s. $115-116$. to odmienne zdefiniowanie przedmiotu opodatkowania. Dotychczas podlegały mu przedsiębiorstwa handlowe, przemysłowe i inne ukierunkowane na osiągniecie zysku oraz wszelkie zawody wolne i inne zajęcia wymienione w taryfie. Ustawa o podatku obrotowym za przedmiot opodatkowania wskazywała wszelkie prywatnoprawne zawodowe i odpłatne świadczenia rzeczy bądź usług wykonywane na obszarze państwa. Obowiązek podatkowy istniał niezależnie od tego, czy wykonywanie świadczeń określonych powyżej odbywało się z zachowaniem warunków przepisanych prawem. Przesunięto tym samym istotę przedmiotu opodatkowania faktycznie na czynności podejmowane w ramach prowadzonej działalności gospodarczej, dla której bez znaczenia były urządzenia i zamiar osiągnięcia zysku, jak w przypadku zlikwidowanych świadectw przemysłowych.

Takie ujęcie przedmiotu opodatkowania pozwalało wyodrębnić trzy zasadnicze kryteria obowiązku podatkowego, tj. prawno-prywatny charakter świadczenia, odpłatność i zawodowość świadczeń. Pierwsze zasadniczo nie powinno się wiązać z trudnościami interpretacyjnymi. Przyjęcie przez ustawodawcę cywilistycznego charakteru świadczenia znajdowało swoje odzwierciedlenie w definicji przedmiotu opodatkowania zawartego w ustawie ${ }^{70}$.

\section{Uwagi końcowe}

Podatek przemysłowy, oparty na archaicznych rozwiązaniach, od początku funkcjonowania budził sprzeciw, szczególnie w kontekście wprowadzenia podatku od obrotu i utrzymywania świadectw przemysłowych. Należy również pamiętać, że same ustawy o podatku przemysłowym były w swej treści niezwykle skomplikowane. Ustawodawca w jednej ustawie starał się uregulować jak największą liczbę zjawisk gospodarczych, co w praktyce niejednokrotnie wymagało autorytarnego wyjaśnienia zakresu jej stosowania $\mathrm{w}$ danym stanie faktycznym przez organy skarbowe lub orzeczenia $\mathrm{NTA}^{71}$.

Niewątpliwie rozwiązania przyjęte względem podatku przemysłowego pozwoliły ustawodawcy uzy-

70 A. Rakower, Reforma ustawy o podatku przemysłowym, „Przegląd Prawa Handlowego” 1939, s. 314.

71 J. Kaliski, Dawne i nowe wątpliwości..., s. 258. 
skać stały dochód do budżetu państwa, a wysokość tego dochodu - jakkolwiek wahała się w zależności od okresu i sytuacji społecznej oraz gospodarczej średnio stanowiła $10 \%$ ogólnych wpływów budżetu państwa. Na przykład w 1926 r. pobrano od podatników 210 milionów złotych tegoż podatku, z czego tylko 25 milionów pochodziło ze świadectw przemysłowych, reszta zaś stanowiła podatek od obrotu ${ }^{72}$. W 1929 r. było to już łącznie 350,4 miliona złotych ${ }^{73}$.

Ustawodawca, widząc wady podatku przemysłowego, dążył do zmian prowadzących do jego racjonalizacji. Niestety do 1938 r. były to wyłącznie deklaracje. Do tego czasu zapewnienie stałych dochodów skarbowi państwa było priorytetowym założeniem konstruowania zasad poboru i wymiaru podatku przemysłowego. Taka sama była przyczyna przerzucenia ciężaru pozyskiwania dochodów państwa na przedsiębiorców - byli oni bowiem traktowani jako grupa podatników dająca swoistą rękojmię stałego dopływu określonych sum pieniężnych. Potwierdza to Stanisław Głąbiński, twierdząc, że uchylenie czy zmiana formy poboru tego podatku była niemożliwa z przyczyn finansowych państwa, gdyż obok podatków pobieranych z monopolu spirytusowego i tytoniowego był on głównym dochodem państwa ${ }^{74}$.

Niewątpliwie powyższa doktryna była pokłosiem opinii wyrażonej jeszcze w 1918 r. przez ówczesnego ministra skarbu Józefa Englicha. Stwierdził on wówczas, że państwo, przeprowadzając reformy podatkowe, będzie się liczyć z zagadnieniami kwestii społecznej przez niedopuszczenie do znacznego obciążenia ekonomicznie słabszych warstw ludności. Tym samym wskazał, że ciężar wszelkich reform i zmian będzie obciążać warstwy bogatsze - czyli przedsiębiorców ${ }^{75}$.

72 S. Głąbiński, Polskie prawo..., s. 60.

$73 \mathrm{~W}$ okresie wielkiego kryzysu widać znaczny spadek wpływów z tego podatku: 1931 rok - 253,6 miliona złotych, 1932 197 milionów złotych. Następnie można zauważyć ponowny wzrost przychodów z tego podatku, jednak wobec zmian w systemie podatkowym dane z lat 1936-1937 i następnych nie są porównywalne z wcześniejszymi, zob. J. Piekałkiewicz, Wplyw przesilenia gospodarczego na dochody z poszczególnych podatków, „Czasopismo Skarbowe” 1932, nr 3, s. 133.

74 S. Głąbiński, Polskie prawo..., s. 60.

75 K. Ostrowski, Polityka finansowa..., s. 73.
Ocena powyższych decyzji i ich konsekwencji nie może być jednoznaczna. Początkowo, aby powstrzymać hiperinflację, rząd wręcz rozpaczliwie poszukiwał źródeł dochodu potrzebnych do przeprowadzenia niezbędnych reform, w tym walutowej. Już w drugiej połowie lat 20., wobec świetnej koniunktury gospodarczej i zrównoważonego budżetu, rząd miał wszelkie instrumenty, aby przeprowadzić niezbędne reformy podatkowe, w tym te dotyczące podatku przemysłowego wnioskowane przez samych przedsiębiorców. Chodziło o konstrukcyjne zerwanie z mechanicznym połączeniem podatków przychodowego i obrotowego. Osiągane w tym okresie nadwyżki podatkowe mogły zostać przeznaczone na pokrycie tymczasowego spadku wpływów z podatku przemysłowego, gdyż reforma niewątpliwie wiązałaby się z obniżeniem obciążeń podatkowych. Co jednak ważne, racjonalizacja systemu podatkowego generuje chwilowe spadki wpływów do budżetu państwa, w perspektywie przyczyniając się jednak do wzrostu dochodów. Jak stwierdza Paweł Grata na podstawie analiz działań podejmowanych przez rząd w okresie kryzysu ekonomicznego pierwszej połowy lat 30., wprowadzanie reform w latach 1927-1929 oraz zaniechanie późniejszych reform paradoksalnie pozwoliło zminimalizować negatywne skutki kryzysu ekonomicznego i drastycznego wzrostu deficytu budżetowego. Utrzymanie parytetu fiskalnego pozwoliło nawet w okresie kryzysowym na wprowadzanie do konstrukcji podatku przemysłowego elementów stymulujących ${ }^{76}$.

Dokonanie oceny zmian wprowadzonych w sferze podatku przemysłowego w 1938 r. nie jest niestety możliwe. Wynika to z oczywistych przyczyn - ustawa, która była wynikiem szerszych reform rządu Eugeniusza Kwiatkowskiego, nie weszła w życie. Z uwagi na fakt zastosowania przez ustawodawcę rozwiązań wynikających z orzecznictwa Sądu Najwyższego i Najwyższego Trybunału Administracyjnego w zakresie stosowania ustawy o podatku przemysłowym nowe przepisy niewątpliwie zostałyby pozytywnie przyjęte przez przedsiębiorców. Co jednak najważniejsze, zlikwidowano świadectwa przemysłowe uznane za rozwiązanie przestarzałe. Uznano je tym samym za anachronizm i zerwano $\mathrm{z}$ taryfą, która ignorowała

76 P. Grata, Polityka podatkowa..., s. 152. 
zdolności płatnicze i rentowność danego przedsiębiorstwa, prowadząc do powstania niczym nieuzasadnionych dysproporcji w obciążeniach podatkowych ${ }^{77}$.

$\mathrm{Z}$ uwagi na powyższy fakt, warto zatem przytoczyć słowa Arkadiusza Rakowera, który stwierdził, że: „nowe ustawy nie są doskonałe, ale doskonałych żaden obywatel od Państwa nie żąda; wystarczy, że nowe ustawy podatkowe są zjawiskiem pozytywnym pod względem techniki prawnej i krokiem naprzód na drodze do reformy obejmującej całokształt naszego systemu podatkowego. Życie gospodarcze, znosząc podwyższone może nowymi ustawami obciążenia podatkowe, znajdzie poszukiwana równomierność obciążenia podatkowego, w szczególności w antyetatystycznych tendencjach ustawy o podatku obrotowym, która wprowadza opodatkowanie o 50\% wyższe obrotu przedsiębiorstw państwowych nieposiadających odrębnej osobowości prawnej, i w ten sposób przyczyni się do wyrównywania zdolności konkurencyjnej pomiędzy przedsiębiorczością prywatną i publiczną"78.

\section{Bibliografia}

Alland A., Podatek przemysłowy od komisu, agentury i pośrednictwa, „Czasopismo Skarbowe” 1926, nr 4.

Alland A., Zasady opodatkowania skupu, uprawianego zawodowo, w celu sprzedaży, „Czasopismo Skarbowe” 1928, nr 3.

Bernhardt W., Polityka podatkowa, „Czasopismo Skarbowe” 1931, nr 8.

Ciągwa J., Autonomia Śląska (1922-1939), Katowice [Muzeum Śląskie] 1988.

Ciągwa J., Śląskie spory o wykładnię wygaśnięcia i utraty mandatu poselskiego w Sejmie Śląskim (w:) S. Grodziski i in. (red.), Vetera novis augere. Studia i prace dedykowane Profesorowi Wacławowi Uruszczakowi, t. 1, Kraków [Wydawnictwo Uniwersytetu Jagiellońskiego] 2010.

Ćwikła L., Prawne aspekty rozwoju turystyki w Polsce w latach 1918-1939, Lublin [Wydawnictwo KUL] 2011.

Fajferek A. (red.), Polityka ekonomiczna, Kraków [Wydawnictwo Akademii Ekonomicznej w Krakowie] 1999.

Franz A., Reasumpcje wymiarów i dodatkowe wymiary państwowego podatku przemysłowego od obrotu, „Czasopismo Skarbowe" 1928, nr 3.

Głąbiński S., Polskie prawo skarbowe, Lwów 1928.

77 A. Witkowski, Podatek obrotowy..., s. 277.

78 A. Rakower, Reforma ustawy..., s. 323.
Grata P., Polityka podatkowa II Rzeczypospolitej. Zarys problematyki, „Rocznik Dziejów Społecznych i Ekonomicznych” 2012, t. 72, s. 129-153.

Hasfeld B. (oprac.), Orzecznictwo podatkowe Najwyższego Trybunału Administracyjnego i Sądu Najwyższego 1924-1936r. Podatek dochodowy, podatek przemysłowy, ordynacja podatkowa, Warszawa [skł. gł. Księgarnia Wydawnictw Prawniczych Marian Ginter] 1937.

Kaliski J., Dawne i nowe wątpliwości przy stosowaniu ustawy o podatku przemysłowym, „Przegląd Prawa Handlowego” 1927. Kary za nieposiadanie świadectw przemysłowych, „Przegląd Skarbowy" 1926, z. 8.

Kwiecień S., Polskie prawo gospodarcze okresu międzywojennego, Lublin [Wydawnictwo KUL] 2016.

Kwiecień S., Ustrój województwa śląskiego w latach 1920-1939, „Imponderabilia” 2012, nr 4.

Landau Z., Tomaszewski J., Gospodarka Polski międzywojennej 1918-1939, t. 1: W dobie inflacji. 1918-1923, Warszawa [Książka i Wiedza] 1967.

Landau Z., Tomaszewski J., Gospodarka Polski międzywojennej 1918-1939, t. 2: Od Grabskiego do Pitsudskiego: okres kryzysu poinflacyjnego i ożywienia koniunktury. 1924-1929, Warszawa [Książka i Wiedza] 1971.

Lipiński K., Określenie oddzielnych zakładów i przedsiębiorstw w podatku przemystowym, „Czasopismo Skarbowe” 1930, nr 10.

Lubowicki J., Pojęcie sprzedaży hurtowej, „Przegląd Skarbowy” 1931, z. 6-7.

Lubowicki J., Uproszczony wymiar podatku obrotowego, „Czasopismo Skarbowe" 1933, nr 9.

Nowopowstajace firmy a podatek przemysłowy, „Czasopismo Skarbowe" 1931, nr 6.

O systemie danin publicznych $w$ Polsce. Prace o charakterze ogólnym, z. 3, Warszawa 1926.

Ostrowski K., Polityka finansowa Polski przedwrześniowej, Warszawa [PWN] 1958.

Piekałkiewicz J., Wplyw przesilenia gospodarczego na dochody z poszczególnych podatków, „Czasopismo Skarbowe” 1932, nr 3. Podatek przemysłowy, „Informator Podatkowy” 1928, cz. 2.

Podatek Przemysłowy, „Przegląd Skarbowy” 1939, z. 5.

Podczaski J., Linje rozwoju administracji skarbowej w Polsce, „Sprawy Skarbowe” 1926, z. 11.

Popiołek K., Śląskie dzieje, Warszawa-Kraków [PWN] 1976.

Rakower A., Reforma ustawy o podatku przemystowym, „Przegląd Prawa Handlowego" 1939, nr 1.

Reforma Podatku Przemysłowego, „Czasopismo Skarbowe” 1930, nr 3. 
Rybarski R., Nauka Skarbowości, Warszawa 1935.

Ślifirczyk M., Wykonanie, niewykonanie i nienależyte wykonanie zobowiązania podatkowego, Warszawa [Wolters Kluwer] 2018.

Świtalski F., Handel hurtowy w świetle ustawy o państwowym podatku przemysłowym, „Czasopismo Skarbowe” 1930, nr 4

Taylor E., Prawo skarbowe Rzeczypospolitej Polskiej, cz. 2, Poznań 1920.

Ulgi w podatku przemystowym dla eksportu, „Czasopismo Skarbowe" 1929, nr 11-12.
Ulgi w podatku przemysłowym dla eksportu, ,Przegląd Skarbowy" 1929, z. 12.

Weinfeld I., Skarbowość polska, Warszawa 1935.

Witkowski A., L. Ćwikła, Recenzja: „Prawne aspekty rozwoju turystyki w Polsce w latach 1918-1939”, Lublin 2011, „Administracja. Teoria - Dydaktyka - Praktyka" 2012, nr 27, s. 195.

Witkowski A., Podatek obrotowy w Polsce, „Zamojskie Studia i Materiały" 2005, z. 3 (18). 